\title{
ROBUSTNESS EVALUATION OF THE CHROMATOGRAPHIC DETERMINATION OF VERAPAMIL HYDROCHLORIDE
}

Introduction. The robustness of an analytical procedure is a measure of its capacity to remain unaffected by small, but deliberate variations in method parameters and provides an indication of its reliability during normal usage.

The aim of the study - the rubustness evaluation of the chromatographic determination of verapamil hydrochloride using Youden's test.

Methods of the research. Youden's test is a reliable method to evaluate the robustness of analytical methods, by means of an experiment design which involves seven analytical parameters combined in eight tests. In the present study, we assessed the robustness of a chromatographic method to quantify verapamil hydrochloride using Youden's test. Hence, it was possible to determine the effect of each analytical parameter in the final analysis results. Youden's test showed to be a simple and feasible procedure to evaluate the robustness of chromatographic methods.

Results and Discussion. Using the criteria of Youden's test, the chromatographic method showed to be highly robust regarding the verapamil hydrochloride content, when variations in seven analytical parameters were introduced. The highest variation in the verapamil hydrochloride content was $0.26 \%$, when the concentration of triethylamine in the mobile phase was altered; a value considerably low and not significant in routine analyses.

Conclusions. Youden's test showed to be a reliable and useful tool for the robustness evaluation of the chromatographic method for verapamil hydrochloride quantitation. By means of this test, it was possible to evaluate the effect of seven analytical parameters in the final result of the analyses. Therefore, Youden's test can be successfully applied for the robustness evaluation in validation process of analytical methods by HPLC.

KEY WORDS: verapamil hydrochloride; validation; robustness; chromatography; quantitative analysis; Youden's test.

INTRODUCTION. The analytical procedure refers to the way of performing the analysis. The steps necessary to perform each analytical test should be described in details. This may include but not limited to: the sample, the reference standard and the reagents preparations, use of the apparatus, generation of the calibration curve, use of the formulae for the calculation, etc.

The evaluation of robustness should be considered during the development phase and depends on the type of procedure under study. It should show the reliability of an analysis with respect to deliberate variations in method parameters.

If measurements are susceptible to variations in analytical conditions, the analytical conditions should be suitably controlled or a precautionary statement should be included in the procedure. One consequence of the evaluation of robustness should be that a series of system suitability parameters (c) L. S. Logoyda, 2017 (e.g., resolution test) is established to ensure that the validity of the analytical procedure is maintained whenever used.

Examples of typical variations are:

- stability of analytical solutions,

- extraction time.

In the case of liquid chromatography, examples of typical variations are

- influence of variations of $\mathrm{pH}$ in a mobile phase,

- influence of variations in mobile phase composition,

- different columns (different lots and/or suppliers),

- temperature,

- flow rate.

In the case of gas-chromatography, examples of typical variations are:

- different columns (different lots and/or suppliers),

- temperature,

- flow rate [1]. 
The evaluation of the robustness of chromatographic methods often is complex and laborious, taking into account the large number of analytical parameters that should be considered to carry out the test. Some authors select specific analytical parameters to be evaluated, introducing small variations in the nominal conditions and the statistical interpretation is performed by means of Student's t-test or ANOVA test. Other wider alternative to determine the robustness of analytical methods is the Youden's test. This test allows not only evaluating the method robustness but also pointing out the influence of each analytical parameter in the final results. The basic idea of Youden's test is not to study one alteration at time but to introduce several changes at once, in such a manner that the effects of individual changes can be ascertained $[2,3]$.

The aim of the work was to evaluate the robustness of the chromatographic method for the quantitation of verapamil hydrochloride, using Youden's test, and determine the analytical parameters that present higher influence in the final results of the analysis.

METHODS OF THE RESEARSH. Verapamil hydrochloride SPhU and raw material were purchased from Darnitsa (Ukraine). The chromatographic analysis of verapamil hydrochloride performed on liquid chromatographs Agilent 1290 and HP 1100 systems. The columns used Nucleosil C18 (4.6×150 $\mathrm{mm}$ with a particle size of 5 microns) and Ascentis Express C18 (column size $4.6 \times 150 \mathrm{~mm}$ with a particle size of 5 microns). The column temperature was $25^{\circ} \mathrm{C}$. The mobile phase consisted of methanol $\mathrm{R}$, water $\mathrm{R}$, acetic acid $\mathrm{R}$ and triethylamine $R$ (55: 44: 1: 0.1 ), at a flow rate of $0.8 \mathrm{ml} / \mathrm{min}$. The detection was performed at $280 \mathrm{~nm}$.

Standard solution. $20.0 \mathrm{mg}$ of verapamil hydrochloride SPhU dissolve in methanol $R$ and dilute with the same solvent to $20.0 \mathrm{ml}$ volume. $5.0 \mathrm{ml}$ of the resulting solution adjusted to $25.0 \mathrm{ml}$ of solvent.

Sample solution. To $20.0 \mathrm{mg}$ of verapamil hydrochloride raw material, add $10 \mathrm{ml}$ of methanol $R$, shake in ultrasonic bath for 10 minutes and add methanol $R$ to the volume of $20.0 \mathrm{ml} .5 .0 \mathrm{ml}$ of the resulting filtrate adjusted to $25.0 \mathrm{ml}$ of solvent.

The robustness evaluation of the chromatographic method for the verapamil hydrochloride quantitation was performed using the method proposed by Youdene Steiner (1975). Seven analytical parameters were selected and small variations were induced in the nominal values of the method. Then, eight runs were performed aiming to determine the influence of each parameter in the final result. The seven analytical parameters employed, as well as the introduced variations are demonstrated at table 1. The analytical conditions at the nominal values are represented by capital letters and the conditions with the small variation are represented by lowercase letters.

The seven parameters and its respective variations were combined in eight assays or chromatographic runs, performed in a random order. Table 2 demonstrates the factorial combination of the parameters for the Youden's test. The analyses results are shown by letters from $s$ to $z$. Hence, when combination 1 was assayed, the obtained result was $s$. When combination 2 was assayed, the obtained result was $t$, and so successively.

In each combination, three injections of each sample and standard solutions were carried out, at the work concentration. After the change of chromatographic column or mobile phase composition, 30 minutes were awaited for system stabilization. The evaluated results in each combination were peak area, retention time (Rt), tailing factor $(\mathrm{T})$, theoretical plates number $(\mathrm{N})$ and verapamil hyrdochloride content.

To determine the influence of variations of each parameter in the final result, the mean of the four values corresponding to the capital letters (nominal conditions) was compared to the mean of the four values corresponding to the lowercase letters (altered conditions). For example, to evaluate the effect of the column temperature in the final result of the analyses, the following equation was employed:

$$
\text { Effect } C / c=(s+u+w+y) / 4-(t+v+x+z) / 4 \quad \text { Eq. (1). }
$$

Table 1 - Analytical parameters and variations for the robustness evaluation of the chromatographic method for verapamil hydrochloride quantitation

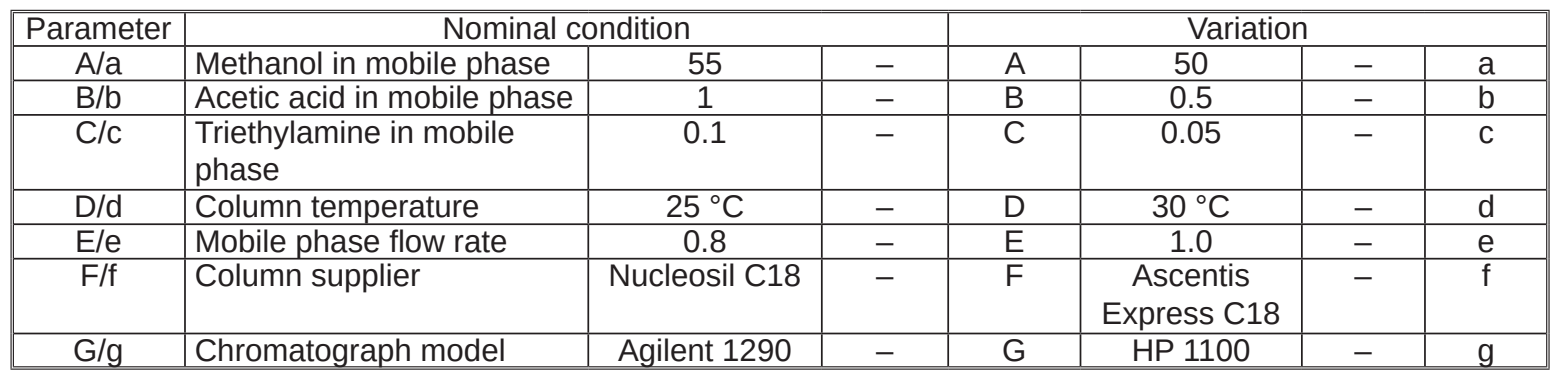


Table 2 - Factorial combination of the analytical parameters for robustness evaluation by Youden's test

\begin{tabular}{|l|c|c|c|c|c|c|c|c|}
\hline \multicolumn{1}{|c|}{ Analytical parameter } & \multicolumn{9}{c|}{ Factorial combination } \\
\hline Methanol in mobile phase & A & A & A & A & a & a & a & a \\
\hline Acetic acid in mobile phase & B & B & b & b & B & B & b & b \\
\hline Triethylamine in mobile phase & C & C & C & C & C & C & C & c \\
\hline Column temperature & D & D & d & d & d & d & D & D \\
\hline Mobile phase flow rate & E & e & E & e & e & E & e & E \\
\hline Column supplier & F & f & f & F & F & f & f & F \\
\hline Chromatograph model & G & g & g & G & g & G & G & g \\
\hline Result & S & t & u & V & w & X & y & z \\
\hline
\end{tabular}

Thus, the influence of the seven analytical parameters regarding the peak area, retention time $(\mathrm{Rt})$, tailing factor $(\mathrm{T})$, theoretical plates number $(\mathrm{N})$ and verapamil hydrochloride content were evaluated. By means of Youden's test, it is possible to establish certainly the parameters which present higher influence in the final result of the analyses and perform a more rigorous control in the eventual variations of these parameters that may occur during a routine analysis.

RESULTS AND DISCUSSION. The assays for the robustness evaluation of the chromatographic method were carried out simultaneously in both equipments, Agilent 1290 and HP1100. The results obtained in the eight runs to the verapamil hydrochloride sample and standard solutions $[4,5]$.

To evaluate the effect of each parameter, the average of the four values corresponding to altered conditions was subtracted from the average of the four values obtained at the nominal conditions, as demonstrated in Eq. (1). The effects of the para- meter variations in the analysis results are presented in Table 3.

Using the criteria of Youden's test, the chromatographic method showed to be highly robust regarding the verapamil hydrochloride content, when variations in seven analytical parameters were introduced. The highest variation in the verapamil hydrochloride content was $0.26 \%$, when the concentration of triethylamine in the mobile phase was altered; a value considerably low and not significant in routine analyses. The retention time of verapamil hydrochloride peak was more considerably influenced by three analytical parameters. The decrease of the methanol, acetic acid and triethylamine concentrations reduced the eluent strength of the mobile phase and induced the increase of the retention time of the verapamil hydrochloride peak. Some parameters such as column temperature, mobile phase flow rate, column supplier and chromatograph model presented low influence in the evaluated factors of the chromatographic method.

Table 3 - Effects of the analytical parameters in content and retention time (Rt) of the chromatographic method for verapamil hydrochloride quantitation

\begin{tabular}{|l|c|c|}
\hline \multicolumn{1}{|c|}{ Effect } & Content, $\%$ & Rt, $\min$ \\
\hline Methanol in mobile phase & $99.72-99.52=\mathbf{0 . 2}$ & $2.54-4.1=-\mathbf{1 . 5 6}$ \\
\hline Acetic acid in mobile phase & $99.71-99.53=\mathbf{0 . 1 8}$ & $2.57-4.3=-\mathbf{1 . 7 3}$ \\
\hline Triethylamine in mobile phase & $99.72-99.46=\mathbf{0 . 2 6}$ & $2.55-4.6=-\mathbf{2 . 0 5}$ \\
\hline Column temperature & $99.64-99.65=-\mathbf{0 . 0 1}$ & $2.45-2.44=\mathbf{0 . 0 1}$ \\
\hline Mobile phase flow rate & $99.64-99.65=-\mathbf{0 . 0 1}$ & $2.62-2.57=\mathbf{0 . 0 5}$ \\
\hline Column supplier & $99.64-99.65=-\mathbf{0 . 0 1}$ & $2.53-2.65=-\mathbf{0 . 1 2}$ \\
\hline Chromatograph model & $99.73-99.76=-\mathbf{0 . 0 3}$ & $2.47-2.32=\mathbf{0 . 1 5}$ \\
\hline
\end{tabular}

CONCLUSIONS. Youden's test showed to be a reliable and useful tool for the robustness evaluation of the chromatographic method for verapamil hydrochloride quantitation. By means of this test, it was possible to evaluate the effect of seven analytical parameters in the final result of the analyses, performing only eight runs. Therefore, Youden's test can be successfully applied for the robustness evaluation in validation process of analytical methods by HPLC.
LIST OF LITERATURE

1. ICH Topic Q2 (R1) Validation of Analytical Procedures: Text and methodology.
2. Isabela da Costa Cesar. Robustness evaluation of the chromatographic method for the quantitation of 
lumefantrine using Youden's test / Isabela da Costa Cesar, Gerson Antonio Pianetti // Brazillian Journal of Pharmaceutical Sciences. - 2009. - № 45. - P. 235-240.

3. Eftichia Karageorgou. Youden test application in robustness assays during method validation / Eftichia Karageorgou, Victoria Samanidou // Journal of Chromatography A. - 2014. - № 1353. - P. 131-139.

4. Logoyda L. Development and validation of new methods of analysis for the determination of different natural and synthetic original active pharmaceutical ingredients in medicines / L. Logoyda // Duphat. - 2015. P. 48.

5. Logoyda L. Validation of chromatographic methods of analysis for the determination of active pharmaceutical ingredients in different medicines / L. Logoyda // Pharma. School Association for Pharmaceutical Development and Scientific Research. Egypt. - 2016. - P. 34.

\section{REFERENCES}

1. ICH Topic Q2 (R1) Validation of Analytical Procedures: Text and methodology.

2. Isabela da Costa Cesar, \& Gerson Antonio Pianetti (2009). Robustness evaluation of the chromatographic method for the quantitation of lumefantrine using Youden's test. Brazillian Journal of Pharmaceutical Sciences. 45(2), 235-240.

3. Eftichia Karageorgou, Victoria Samanidou (2014). Youden test application in robustness assays during method validation. Journal of Chromatography A, 1353, 131-139.
4. Logoyda L. (2015). Development and validation of new methods of analysis for the determination of different natural and synthetic original active pharmaceutical ingredients in medicines. Duphat; 48.

5. Logoyda L. Validation of chromatographic methods of analysis for the determination of active pharmaceutical ingredients in different medicines. Pharma. School Association for Pharmaceutical Development and Scientific Research, 34.

\section{АНАЛІЗ РОБАСТНОСТІ ХРОМАТОГРАФІЧНОГО ВИЗНАЧЕННЯ ВЕРАПАМІЛУ ГІДРОХЛОРИДУ}

\section{Резюме}

Вступ. Робастність - це здатність аналітичної методики не зазнавати впливу малих заданих аналітиком змін під час виконання методики, є показником надійності методики при ії використанні у вказаних умовах.

Мета дослідження - проаналізувати робастність хроматографрічного визначення верапамілу гідрохлориду із застосуванням Юден тесту.

Методи дослідження. Випробування Юден тесту є надійним методом аналізу робастності аналітичних методів за допомогою планування експерименту, який включає сім аналітичних показників, об'єднаних у вісім випробувань. У цьому дослідженні оцінено робастність хроматографрічного методу для кількісного визначення верапамілу гідрохлориду з використанням Юден тесту. Отже, можна визначити вплив кожного аналітичного параметра в кінцевих результатах аналізу. Юден тест показав, що він $\epsilon$ простим і доступним у процедурі оцінки робастності хроматографрічних методів.

Результати й обговорення. При використанні критеріїв Юден тесту хроматографрічний метод показав високу оцінку робастності щодо вмісту верапамілу гідрохлориду, коли було змінено сім аналітичних параметрів. Найбільша варіація у вмісті верапамілу гідрохлориду становила 0,26 \%, коли була змінена концентрація триетиламіну в рухомій фразі.

Висновки. Юден тест є надійним і корисним для оцінки надійності хроматографрічного методу кількісного визначення верапамілу гідрохлориду. За допомогою цього тесту можна оцінити вплив семи аналітичних параметрів у кінцевих результатах аналізу. Таким чином, Юден тест можна успішно застосовувати для оцінки робастності в процесі валідації аналітичних методів за допомогою високоесрективної рідинної хроматографрії.

КЛЮЧОВІ СЛОВА: верапаміл гідрохлорид; валідація; робастність; хроматографія; кількісний аналіз; Юден тест. 


\section{АНАЛИЗ РОБАСТНОСТИ ХРОМАТОГРАФИЧЕСКОГО ОПРЕДЕЛЕНИЯ ВЕРАПАМИЛА ГИДРОХЛОРИДА}

\section{Резюме}

Вступление. Робастность - это способность аналитической методики не подвергаться влиянию малых заданных аналитиком изменений во время выполнения методики, является показателем надежности методики при ее использовании в указанных условиях.

Цель исследования - проанализировать робастность хроматографического определения верапамила гидрохлорида с применением Юден теста.

Методы исследования. Испытание Юден теста является надежным методом анализа робастности аналитических методов с помощью планирования эксперимента, который включает семь аналитических показателей, объединенных в восемь испытаний. В этом исследовании оценена робастность хроматограсрического метода для количественного определения верапамила гидрохлорида с использованием Юден теста. Итак, можно определить влияние каждого аналитического параметра в конечных результатах анализа. Юден тест показал, что он является простым и доступным в процедуре оценки робастности хроматографических методов.

Результаты и обсуждение. При использовании критериев Юден теста хроматографрический метод показал высокую оценку робастности относительно содержания верапамила гидрохлорида, когда были изменены сем аналитических параметров. Наибольшая вариация в содержании верапамила гидрохлорида составляла 0,26 \%, когда была изменена концентрация триэтиламина в подвижной фразе.

Выводы. Юден тест надежен и полезен для оценки надежности хроматографического метода количественного определения верапамила гидрохлорида. С помощью этого теста можно оценить влияние семи аналитических параметров в конечных результатах анализа. Таким образом, Юден тест можно успешно применять для оценки робастности в процессе валидации аналитических методов с помощью высокоэффрективной жидкостной хроматографрии.

КЛЮЧЕВЫЕ СЛОВА: верапамил гидрохлорид; валидиция; робастность; хроматография; количественный анализ; Юден тест.

Received 12.01.17

Address for correspondence: L. S. Logoyda, I. Horbachevsky Ternopil State Medical University, Maidan Voli, 1, Ternopil, 46001, Ukraine, e-mail: logojda@tdmu.edu.ua. 